International

Medical Society

http://imedicalsociety.org

\title{
Record in the Perception of Health Professionals
}

ORIGINAL

\begin{abstract}
Célia Maria Cartaxo Pires de Sá1, Maria Adelaide Silva Paredes Moreira², Karoline de Lima Alves ${ }^{3}$, Lenilde Duarte de Sá4 ${ }^{4}$ Maria de Lourdes de Farias Pontes ${ }^{4}$, Jorge Correia Jesuíno5, Maria Filomena Mendes Gaspar6, Greicy Kelly Gouveia Dias Bittencourt', Ana Paula Abreu Borges ${ }^{8}$, Antonia Oliveira Silva ${ }^{4}$
\end{abstract}

\section{Abstract}

Introduction: The population growth of older people is a reality that requires a different look at all care levels. The Elderly's Health Record (EHR) was created to identify the vulnerabilities and peculiarities of this population and promote specific actions.

Objective: To investigate the perspective of primary care professionals about the record.

Method: An exploratory and qualitative study, carried out in Family Health Units at Sanitary District V in the city of João Pessoa, Paraíba/ Brazil, in which participated 53 health professionals. A semi-structured interview with questions related to the use of the EHR by professionals and socio-demographic information was used. Data were analyzed using Thematic Content Analysis - Categorical Technique, which returned six categories: a) care tool; b) Instrument for autonomy for the elderly; c) Use of information on the health of the elderly; d) Object of work; e) health monitoring Guide elderly and f) Health Support.

Results: Of the respondents, $86.8 \%$ use the EHR; $3.8 \%$ do not know and $9.4 \%$ have access, but do not use it. Professionals associate it in positive and negative concepts and opine in favor of its use by contemplating valuable information to be considered in health care for the elderly.

Conclusion: Grasping the perspective of professionals related to the HER will contribute to support discussions and increase the number of accession to it as a health promotion tool in aging.
1 Nutritionist. Master in Nursing. F.U.P.

2 Physiotherapist. Doctor. F.U.P.

3 Nurse. Master in Nursing. F.U.P.

4 Nurse. Doctor. F.U.P.

$5 \mathrm{PhD}$ in Sociology. Researcher at the Institute of Social and Political Sciences (ISCSP), Technical University of Lisbon.

6 Nurse. President/Teacher of the Lisbon Nursing School. Lisboa, Portugal.

7 Nurse. F.U.P.

8 PhD in Public Health of the National Public Health School, Universidade Nova de Lisboa, Portugal.

F.U.P.: Federal University of Paraíba, João Pessoa, Paraíba, Brazil.

Contact information:

Karoline de Lima Alves.

Đ krol_lima_17@hotmail.com

\section{Keywords}

Health Professionals; Health Handbook Elder; Aging. 


\section{Introduction}

The growing number of elderly people in the population is a visible phenomenon, especially in the late twentieth century, when analyzing the proportion of markedly elderly in all spheres of society. The state must follow the reality of the age structure and all its consequences, for the investments' balance to be positive and endorse the potential of this population. [1]

Population aging is a common feature in the demographic dynamics of world population. In Brazil, the population aged 60 or more increased from $4 \%$, in 1940 , to $11 \%$ in 2010 , with the expectation of reaching $28 \%$ by 2040 - something around 57 million elderly. This involves changes in the pattern of transfers of public and private resources. [2]

The Northeast of Brazil has the lowest proportion of older people, with about $9 \%$ of the population in this age group, and the state of Paraiba, entered the national scene, has the third largest population of elderly, with $9.12 \%$ of people over 60 years of age. Second in a matter of elderly number only to the states of Rio de Janeiro (12.7\%) and Rio Grande do Sul (12.5\%). [3]

In Brazil, in 2006, the National Health Policy for the Elderly (NHPFE) was implemented, which directs the individual and collective health measures for the elderly population, in accordance with the principles and guidelines of Unified Health System (SUS). By NHPFE, the Ministry of Health created and distributed to all Brazil, in October 2006, the Elderly's Health Record (EHR), to identify the general framework of the elderly situation across the country, and promote specific actions to this age group health needs. [4].

The EHR should be used by professionals of the Family Health Strategy (FHS) in care for the elderly, since it enables the development of actions aimed at comprehensive care, aiming to reduce mortality, identify the elderly frail or dependent, immunize effectively and adequately monitor the elderly at risk of harm. [5].
This tool allows the health professionals to record important information about the health conditions of the elderly and inform them of what actions must be initiated to promote an active and healthy aging under the Primary Care (PC). In this perspective, the health system and universities should work together to improve the space where the health needs of the population arise, and invest in the quality of professionals training. [6].

The comprehensive care requires as a prerequisite a job performed by a multidisciplinary team. In this context, priority is the development of skills of health professionals to work, especially when the actions of promotion, prevention, care and recovery have as core the care for the elderly. [7]

It is pertinent to investigate the movement caused by these perceptions, in order to understand the dynamics of health to readjust practices, especially those aimed at the elderly, who need a comprehensive health care due to its peculiarities. Thus, it is necessary to promote knowledge that is produced daily in health facilities and harness it with what is created at the university. [8]

The use of EHR by professionals for the planning of health actions for this population is reflected in a practice that allows a more comprehensive care.

The aim of this study is to investigate how the professionals of the family health strategy conceive HER, and adherence or not to use by these professionals in care for the elderly.

\section{Method}

This is an exploratory research with a qualitative approach, approved by the Research Ethics Committee of the Health Sciences Center of the Federal University of Paraíba - CEP/ CCS, to the CEP/ HULW n० 261/09 and CAEE 0182.0.126000-09. The ethical principles set out in Resolution 196/96, in force at the time, were respected, and the Instrument of Consent of the National Health Council signed. [9] 
The study included 53 professionals - 19 nurses, 15 technicians of Nursing and 19 doctors, chosen at random, for convenience, that is with the professionals who were available at data collection, and was carried out in Family Health Units at Sanitary District $V$ in the city of João Pessoa, Paraíba/Brazil, from December 2014 to April 2015.

The inclusion criteria of the subjects were: the status of work in the 18 family health teams that were part of the family health strategy of the Sanitary District V; take part in the research; respond to the data collection instrument and sign the Consent Term (CT).Data were collected with semi-structured interview containing questions related to the use of the EHR by professionals and socio-demographic information, and then analyzed using Thematic Content Analysis - Categorical Technique [10]. Demographic data were grouped with the help of Excel 2010 computer program for the variables: gender, age, marital status, education, occupation and length of service.

Regarding the limitations of this study as the sample of nursing techniques, one refused to participate and two were on vacation during collection period. The doctors refused to participate in the research, and only one male person took part in the research.

\section{Results}

The profile of the participants was defined, aiming to know their characteristics in the social context. The study group consisted of 53 health professionals, aged between 23 and 68 years. The age group that had the highest number of professionals was 51-60 years with $28.3 \%$, the majority $(98.1 \%)$ belonging to the female, and only a professional male from primary care team $(A B)$, agreed to volunteer research.

It was observed that $60.4 \%$ of the respondents were married. For education, the study showed that $52.8 \%$ attended a Specialty (lato sensu), and 20.8 $\%$ completed higher, $11.3 \%$ incomplete higher,
$3.8 \%$ level Master (stricto sensu); there is a difference between Lato Sensu meaning "in a broad sense" and understands the courses focusing on some specialization and Stricto Sensu means "narrow sense", is restricted to masters and doctoral courses, and higher level it is of undergraduate courses in education, refers to first university title received by an individual, the term graduation is also associated to daily training idea of higher level. Regarding training, professionals belonged to three specific sections: nurses (35.8), doctors (35.8\%) and nursing technicians (28.4\%).

About the time of service, the highest percentage (24.5\%) corresponded to the range from one to ten years, as described in Table 1.

Table 1. Professional distribution according to sociodemographic variables.

\begin{tabular}{|c|c|c|c|}
\hline \multirow[b]{2}{*}{ Varible } & \multirow[b]{2}{*}{ Category } & \multicolumn{2}{|c|}{ Frequency } \\
\hline & & $\begin{array}{c}\text { Absolute } \\
\text { (n) }\end{array}$ & $\begin{array}{c}\text { Relative } \\
(\%)\end{array}$ \\
\hline \multirow{2}{*}{ Gender } & Male & 1 & 1.9 \\
\hline & Female & 52 & 98.1 \\
\hline \multirow{5}{*}{ Age } & $20-30$ years & 12 & 22.6 \\
\hline & $31-40$ years & 10 & 18.9 \\
\hline & $41-50$ years & 8 & 15.1 \\
\hline & $51-60$ years & 15 & 28.3 \\
\hline & +60 years & 8 & 15.1 \\
\hline \multirow{4}{*}{$\begin{array}{l}\text { Marital } \\
\text { Status }\end{array}$} & Single & 12 & 22.6 \\
\hline & Married & 32 & 60.4 \\
\hline & Divorced & 2 & 3.8 \\
\hline & Widow(er) & 7 & 13.2 \\
\hline \multirow{5}{*}{ Education } & Technical Course & 6 & 11.3 \\
\hline & Incomplete College & 6 & 11.3 \\
\hline & College & 11 & 20.8 \\
\hline & Expertise & 28 & 52.8 \\
\hline & Master Course & 2 & 3.8 \\
\hline \multirow{3}{*}{ Profession } & Nursing Technician & 15 & 28.4 \\
\hline & Nurse & 19 & 35.8 \\
\hline & Physician & 19 & 35.8 \\
\hline
\end{tabular}




\begin{tabular}{|l|l|c|c|}
\multirow{2}{*}{ Varible } & \multicolumn{1}{|c|}{ Category } & \multicolumn{2}{|c|}{ Frequency } \\
\cline { 3 - 4 } & Less than one year & 6 & 11.3 \\
& From one to tem years & 13 & 24.5 \\
\hline Time of & 11 to 20 years & $\begin{array}{c}\text { Relative } \\
(\%)\end{array}$ \\
\hline Service & 21 to 30 years & 12 & 22.6 \\
\hline & +30 years & 11 & 20.8 \\
\hline Total & & 11 & 20.8 \\
\hline
\end{tabular}

Source: Search, 2015

\section{Information or Knowledge}

The contents of the EHR, defined in six categories, are addressed in Table $\mathbf{2}$.

Table 2. Descriptions of the categories from the content analysis focused on the speeches of professionals about the EHR.

\begin{tabular}{|l|l|}
\multicolumn{1}{|c|}{ Categories } & \multicolumn{1}{c|}{ Descriptions } \\
\hline 1 Care tool & $\begin{array}{l}\text { Include the analysis units on the } \\
\text { relevance of the EHR as a care tool } \\
\text { for the elderly in the FHS. }\end{array}$ \\
\hline $\begin{array}{l}\text { Instrument of } \\
\text { autonomy for the } \\
\text { elderly }\end{array}$ & $\begin{array}{l}\text { Comprises the analysis units about } \\
\text { the importance of EHR as an } \\
\text { autonomy instrument for elderly. }\end{array}$ \\
\hline $\begin{array}{l}\text { Health information } \\
\text { guide }\end{array}$ & $\begin{array}{l}\text { Corresponds to the analysis } \\
\text { units about the use of EHR as } \\
\text { an information guide about the } \\
\text { elderly's health. } \\
\text { Addresses the analysis units in } \\
\text { Which EHR is set up as a working } \\
\text { object. }\end{array}$ \\
\hline
\end{tabular}

5 Elderly health Emphasizes the analysis units monitoring feature related to the HER use as a followup feature on the elderly's health.

6 Health Support Highlights the analysis units in which professionals express the meaning of EHR as a health support.

\section{Category 1. Care Tool}

To operationalize the National Health Policy for the Elderly, two major population groups are considered: a) the independent elderly and b) the frail elderly or in weakening process. The first are those elderly people who, even if suffering from some disease (the most common are hypertension and diabetes), remain active in the family and in the social environment. Fragile elderly or in weakening process are those who have certain conditions that can be identified by health professionals. The purpose of EHR is to identify the latter group, to prioritize recovery, promotion and attention actions, and prevent the worsening of the health condition. [11].

Professionals understand the EHR as a care tool. [12]. The reports below confirm this assertion:

[...] Is of great importance that the elderly have the EHR at the time of service, because it shows the previous history, how is the health, if previous reviews are correct, blood pressure, blood glucose, as the [...] blood pressure is like a mirror, so that we can take care of their health [...] If the elderly brings the book duly completed with all the data, we have a notion that the patient is being attended, or is a patient who never attends regular consultations, so we have a health notion that patient at that time. Although most forgets [...].

Professionals: $05 ; 12 ; 14$; etc.

Professionals also reveal that, before the organic illness, the elder presents some signs of risk and has to identify these signals, so that action can be taken at an early stage.

\section{Category 2. Instrument of autonomy for the elderly} The views expressed by health professionals considered EHR as an instrument of autonomy for this population, as shown by some representative content: 
[...] Are important data for the elderly, for family and for any needs [...] because it has many instructions, and says that the elderly should always check blood pressure, blood glucose, making a daily control [...] is an instrument that serves as a guide for themselves, many can read and identify many problems related to them. They can learn by reading the records that the old book [...] has some guidelines for hypertensive and diabetic patients also have follow-up, they have to come here to record blood pressure, blood glucose, and make clinical follow-up, especially of hypertension and diabetes [...].

Professionals: 2, 9, 28, 45.

However, there are reports of some health professionals with negative content regarding the use of EHR for this purpose, in which they reveal the lack of care and attention for the elderly during the service, as shown by these thematic cutouts:

[...] Unfortunately, the elderly not always uses it because helshe does not have the information. Sometimes the professional is not careful to steer the elderly properly, talking about the importance of HER and the duty to always carry it in the purse. So they think it is something to be used only once a week when you go to the health facility, or once a month when you will pick up the medication, and the importance of the EHR goes far beyond [...] but we see that the elderly person is not aware of the importance of their EHR, because several times we asked the EHR and helshe left at home, bringing only other documents [...].

Professionals: 44, 48, 51, among others.

Such conceptions influence attitudes and reinforce the idea that there are weaknesses in the work process of the FHT professionals, which may be related to the low professional qualification to recognize the needs of this group, contradicting the National Health Policy for the Elderly, which establishes mechanisms that are employed to improve the quality of care for the elderly should be incorporated in health care of this population, with the involvement of primary care professionals and family health teams [13].

\section{Category 3. Information guide about the health of the elderly.}

In their statements, the professionals highlighted the range of information that is included in the EHR and said that this is a complete instrument that contains valuable information for monitoring this population. They emphasize also the importance of this content to the seizure of real knowledge about the health of the elderly:

[...] The EH,R recommended by the Health Ministry, identifies the elderly, identifies the conditions in which the elderly live, identifies the people who care for the elderly, identifies the health status, the disease and medications helshe takes, monitoring of blood pressure and blood glucose, if the elderly are diabetic, weight, vaccine and gives some further guidance. It is complete [...] is important as a mirror of health, because it has a very particular information of the elderly, about allergic to any medication [...] which is the medicine that the elderly are using, what is the disease that it is a carrier, which is the medicine that the elderly are allergic and cannot use, is noted. It is rich in information [...] is where all his/her personal information, clinical status, so EHR has great importance. It is a summary of the most important things, because it has the medical history we can put [...] and the health team can still articulate and thus fill in other ways too, adding deemed relevant data [...]

Professionals: 1; 12; 33; 44; etc. 


\section{Category 4. Working Object}

According to the professionals' speeches, the EHR is essential for the establishment of a care plan that meets elderly needs, which is configured as a guiding principle for the work process at attending, whether routine or emergency.

[...] we have control of how is his/her daily life, if every time helshe comes to the health facility, if helshe is keeping controlled pressure, the guidelines that have been made for the hypertensive and diabetic mainly, and other seniors with the morbidities that are over 60 years, and not only of hypertension and diabetes, because it has old that is not hypertensive. Serves to plan actions [...] when an old man fainted, we saw that it was hypertension, diabetes was high, all helped plan the intervention at that time [...] helps us to have a north for senior care [...]

Professionals: 2; 18; 36; among others.

\section{Category 5. Accompanying elderly health resource}

Professionals refer to EHR as an accompanying feature of elderly health, since it enables health promotion and disease prevention, minimizing risks and hazards. This contributes to structure the attention to the elderly, as shown by these statements:

[...] I use the EHR usually to accompany the patient's drug. Usually the elderly arrives and we do the record. We see how many drugs were given, never missing medication, and also for him/ her to have an orientation [...] and, for us professionals, it is a way of monitoring what medication he/she is using, some changes. It is a way to help all professionals see what is being used, and also to read and learn something about his/ her health [...] in short, the EHR helps to plan interventions, plan a better thing for the elderly [...]is important for the monitoring of the elderly, to see if helshe is coming, to follow up, making actions, always in partnership with people in older age groups, a nutritionist gives a speech, other speech another matter [...]

Professionals: 28; 32; 37; 42, among others.

\section{Category 6. Health Support}

The speeches' contents highlight EHR as a health support for both the elderly and health professionals themselves, to improve care and protection:

[...] Because EHR records the query frame, returns to health unit, blood pressure; helshe suddenly gets sick in the middle of the street and you are with your HER, we already know that helshe is diabetic, whether the blood pressure is controlled or not [...] is very important to know if the elderly really have the record on security issue. It is important that the elderly need to bring the EHR [...]also serves to feel safer in case of a change of treatment [...]

Professionals: 2; 13; 19; 38; among others.

\section{Positioning and Attitude}

Health professionals have opined on the use of EHR favorably $-86.8 \%$ said they use it, $3.8 \%$ said they did not know, and $9.6 \%$ said they have access, but do not use it, as shown in Table 3.

Table 3. TPositioning of professionals on the use of EHR - João Pessoa/2015

\begin{tabular}{|l|c|c|}
\hline \multirow{2}{*}{$\begin{array}{c}\text { Professional's } \\
\text { opinion }\end{array}$} & \multicolumn{2}{|c|}{ Frequency } \\
\cline { 2 - 3 } & Absolute $(\mathrm{n})$ & Relative (\%) \\
\hline Uses & 46 & 86.8 \\
\hline Unknown & 2 & 3.8 \\
\hline Have, but do not use & 5 & 9.4 \\
\hline Total & 53 & 100 \\
\hline & Source: Author's research, 2015.
\end{tabular}




\section{Discussion}

Regarding gender, there is a predominance of women working in the USF. This corroborates a study [14] on the social representations of workers of primary care related to aging, which showed the supremacy of the female workforce in the FHS.

The distribution of participants by age range 2368 years, with predominance of the age group 51 to 60 years. These data meet the one on the study [15] done by Costa et al. (2013), which addressed the human resources in family health strategy, emphasizing the category age group, especially the inclusion of professionals in the FHS, both early in his career and long working life.

Regarding marital status, $60.4 \%$ of the respondents were married. These data are similar to those found in other study [16], which identified 70.8\% of married professionals, setting up an increasing number of tasks and responsibilities in their daily lives.

In terms of training for work in the ESF, the study showed that $52.8 \%$ of college-educated professionals have expertise in public health. The reality identified in this study differs from findings relating to professionals with higher education found in research done in Montes Claros on the socio-demographic characteristics of workers in the ESF, with regard to qualification for the job, it was found that only $19.9 \%$ professionals had completed college. [17].

Regarding the length of time in service, it was found that $24.5 \%$ of the professionals worked in the family health strategy for a period of one to ten years. These data differ from those found in another study [18], which highlighted that the professionals working time, from the trade, was 48 months on average, which points to a significant turnover of these professionals in the field of primary care.

They claim that the EHR is a tool used to condense the data and the most important records about health, both for it and for health professionals. The EHR was launched by the Ministry of Health, in or- der to provide and disseminate all relevant information of the elderly, facilitate the approach and tackle the most prevalent diseases in this population. While European countries such as Italy, Denmark, Germany and the Netherlands have adopted other strategies to facilitate the care of the elderly, Brazil presented the book as workup for comprehensive care.

According to a study [19], the group of elderly respondents represented EHR as a policy instrument, since it contains important recommendations on their health and enables learning and autonomy. This representation is positively related to the views expressed by the professionals interviewed in this study. In this sense, the testimonies converge to a study conducted at the Paulista State University, which investigated the social representations of concepts "diabetes" and "diabetic foot" among diabetics, non-diabetic patients and health professionals, and identified, in the report of the interviewed users, claims related to the importance of physical activity for the treatment of diabetes, in order to benefit it. The study found that the awareness of this population, regarding their health situation, favors the maintenance of their physical and functional capacity. [21]

Considering the study [22] on fostering the elderly and the systematization of nursing in primary care, EHR proved to be a suitable instrument to implement the systematization of nursing in primary care, with regard to the proposed interventions which addressed on physical activity, smoking reduction, improved social interaction, control of drug use, evaluation/dietary counseling and blood pressure and glycemic control, which contribute to the promotion of autonomy and independence of older people.

During the $12^{\text {th }}$ Brazilian Congress of Medicine, Family and Community in Belém, the EHR was presented as a management tool in the Family Health Teams. Its use was compared to a mini medical record, which contains the main health records of the 
elderly, not only facilitating the care of the support for this population, but also promoting the updating of information system data from the Ministry of Health, and the enhance of new shares and strategic goals aimed at this population group. [22].

This range is verified in a study [24] on the implementation and monitoring of EHR in the Family Health Strategy, which aims to CSPI as a proposal that has contributed to the production of good quality information aiming to offer the elderly a comprehensive care.

A study presents [25] a literature review as a substrate for the creation of a new expanded medical evaluation tool, to apply on medical consultation in elderly patients in primary care. In this study, the EHR was appointed as a joint tool among primary care professionals and the elderly, which facilitates the identification of clinical and functional vulnerabilities, monitor chronic diseases and warn of the medications that are potentially risk for the elderly, reaching the specific problems and complications in the health of this population.

In the municipality of Caririaçú (EC), the EHR was adopted with the aim of humanizing actions and improve service in health during the year of 2008. All the Family Health Teams linked to Municipal health Bureau received copies for use by health professionals. The nurses lead the management and use of this instrument. Although it was not mentioned specifically, this management is checked when the professionals claim in their speeches that older people who adhere to use the services have the book as a personal and health reference document. [7].

Assessing [25] the actions and services available to seniors who are attended in primary care in the city of Campina Grande - PB, the EHR reveals for the professionals and the elderly individual risk factors and enhances the preventive, curative or recovery cares of this population. They emphasize that, aware of all needs, seek to improve the quality of life. This study also revealed that $76 \%$ of profes- sionals involved listed as allocation of professionals from the Family Health Units the filling, delivery and updating of EHR, which is a security tool for those involved in the care process.

For the professionals who said they do not know EHR, they demonstrated the total lack of understanding about the instrument. As for those who said they had access to it, but not used, it is concluded that they did not understand the importance of its use in the work process.

Regarding literature limitations on the subject of health booklet Elder, notes the scarces publications, justified by being a new topic rarely addressed on literature.

\section{Conclusion}

This article aimed to investigate how professionals in the family health strategy conceive the elderly's health record, and whether they adhere or not to use it in care for the elderly.

Thus, professionals analyzed the record with predominantly positive content, associating it with positive concepts and positioned themselves favorably to the use of it, contemplating valuable information to be considered in elderly's health care, in order to consolidate public policy health care aimed at an active and healthy aging.

It is noteworthy, however, that there were also negative content, in which professionals showed that they have difficulties to adhere to the use of EHR in care for the elderly, as a tool that affords access to the necessary guidelines for the monitoring of their health conditions, which suggests the need to redefine the aging process in primary care, in order to improve the quality of the offered shares.

It is expected that this study will contribute to propose discussions focused on expanding the membership to use the EHR in the health services at the senior care, as well as to create new strategies to confront the work process failures established in these locations. 
The research limitations can be addressed in future research on the care given to elderly health, especially concerning publications and the sample size, which should be performed in all the Family Health Units; so it is possible to know what they think the health professionals on the use of booklet for the elderly health.

\section{Contribution of authors}

CMCPS, KLA, and MASPM worked in all phases of development, from conception, design, analysis and interpretation of the data, writing of the manuscript; CMCPS and KLA prepared the database; CMCPS performed critical review of the manuscript; LDS, MLFP, AOS, MASPM, conducted orientation of the manuscript and approved the final version to be published.

\section{Conflict of interest}

The authors declare the absence of conflict of interest.

\section{References}

1. Zanon, RR, et al. Envelhecimento populacional e mudanças no padrão de consumo e na estrutura produtiva brasileira. Rev Bras de Estud de Popul., 2013; 30: 45-67.

2. Instituto de Pesquisa Econômica Aplicada. Texto para discussão. Instituto de Pesquisa Econômica Aplicada. Brasília: Rio de Janeiro. (2013).

3. Instituto Brasileiro de Geografia e Estatística. Censo demográfico: 2010. Rio de Janeiro. [Internet] 2010. [Acesso em: dezembro de 2015]. Disponível em: <http://www.ibge. gov.br/censo/default.php>

4. Ministério da Saúde. Portaria GM n².528 de 19 de outubro de 2006. Política Nacional de Saúde da Pessoa Idosa. Brasília/Brasil. (2006).

5. Ministério da Saúde. Secretaria de Atenção à Saúde. Caderneta de saúde da pessoa idosa: manual de preenchimento. Brasília/ Brasil. (2008)

6. Gonze GG, Silva GAA. Integralidade na formação dos profissionais de saúde: tecendo valores. Physis. Revista de Saúde Coletiva, Rio de Janeiro. 2011; 21(1): 129-146.

7. Barros TB, Maia ER, Pagliuca LMF. Facilidades e dificuldades na assistência ao idoso na estratégia de saúde da família. Rev Rene. 2011; 12(4): 732-741.
8. Araújo D, Miranda MCG, Brasil SL. Formação de profissionais de saúde na perspectiva da integralidade. Rev. baiana saúde pública. 2007; 31(1): 20-31.

9. Ministério da Saúde. Conselho Nacional de Saúde. Resolução 96, de 14 de novembro de 1996. Diretrizes e Normas Regulamentadoras de Pesquisas envolvendo seres humanos. Brasília/Brasil: CONEP. (1996).

10. Bardin L. Análise de Conteúdo. 70 ed. Lisboa; 2009.

11. Ministério da Saúde. Portal da Saúde. Caderneta de saúde da pessoa idosa. Brasília/Brasil. [Internet] 2014. [Acesso em outubro de 2015]. Disponível em: http://portalsaude.saude.gov. br/index.php/o-ministerio/principal/secretarias/sas/daet/saudeda-pessoa-idosa.

12. Ayres JRCM. O cuidado, os modos de ser (do) humano e as práticas de saúde. Revista Saúde e Sociedade. 2004; 13(3): 1629.

13. Ministério da Saúde. Departamento de Atenção Básica. Política Nacional de Atenção Básica. v.04. Série Pactos pela Saúde. Brasília. (2006).

14. Mendes CKTT, et al. Representações sociais de trabalhadores da atenção básica de saúde sobre envelhecimento. Rev Gaúcha Enferm. 2012; 33(3): 148-155.

15. Costa SM, et al. Perfil do profissional de nível superior nas equipes da Estratégia Saúde da Família em Montes Claros, Minas Gerais, Brasil. Rev Bras Med Fam Comunidade. 2013; 8(27): 90-96.

16. Zanetti TG, et al. Perfil socioprofissional e formação de profissionais de equipes de saúde da família: um estudo de caso. Cienc Cuid Saude. 2010; 9(3): 448-455.

17. Fonseca FF, et al. Caracterização sociodemográfica e ocupacional de trabalhadores da estratégia de saúde da família. Revista Eletrônica Gestão \& Saúde. 2014; 5: 2465-78.

18. Pinto ESG. Situação de trabalho dos profissionais da Estratégia Saúde da Família em Ceará-Mirim. Rev Esc Enferm USP. 2010; 44(3): 657-664.

19. Dantas KMVP. Caderneta de saúde da pessoa idosa no olhar dos idosos atendidos na Estratégia de Saúde da Família. [Dissertação]. Centro de Ciência da Saúde. Universidade Federal da Paraíba; 2015.

20. Mendes TAB, et al. Diabetes: prevalência, práticas de controle e uso de serviços de saúde. Cad. Saúde Pública. 2011; 27(6): 12331243.

21. Mantovani AM, et al. Estudo comparativo das representações sociais sobre diabetes mellitus e pé diabético. Cad. Saúde Pública. 2013; 29(12): 2427-2435.

22. Carvalhêdo FG, et al. Acolhimento ao idoso e sistematização da assistência de enfermagem na atenção primária. Rev Enferm UFPE. 2015; 9(1): 143-148. 
23. De Lima Borges $L$, et al. Caderneta de saúde da pessoa idosa como ferramenta de gestão na ESF. ANAIS DO CBMFC. 2013; 12: 1464.

24. Ferreira MGS. Implantação e monitoramento da caderneta de saúde da pessoa idosa na estratégia de saúde da família: a experiência da área programática do município do Rio de Janeiro. [Dissertação]. Universidade Estácio de Sá, 2010.

25. Silva TC, et al. Instrumento de Avaliação Médica Ampliada para aplicação em consultas médicas a pacientes idosos na atenção básica. Revista de Iniciação Científica da Universidade Vale do Rio Verde. 2015; 5(1): 13-22.

Publish in International Archives of Medicine

International Archives of Medicine is an open access journal publishing articles encompassing all aspects of medical science and clinical practice. IAM is considered a megajournal with independent sections on all areas of medicine. IAM is a really international journal with authors and board members from all around the world. The journal is widely indexed and classified Q1 in category Medicine. 